\title{
Efficacy of Fungicides on the Management of Sheath Blight of Rice
}

\author{
R. Ganesha Naik ${ }^{1}$, K. Jayalakshmi ${ }^{1 *}$ and T. Basavaraj Naik ${ }^{2}$ \\ ${ }^{1}$ Department of Plant Pathology, ${ }^{2}$ Department of Agronomy, University of Agricultural and \\ Horticultural Sciences, Shivamogga, 577204, Karnataka, India \\ *Corresponding author
}

\begin{tabular}{|c|c|}
\hline \multicolumn{2}{|r|}{ A B S T R A C T } \\
\hline & \multirow{6}{*}{$\begin{array}{l}\text { Sheath blight of rice is an economically important disease affecting rice production. Nine } \\
\text { fungicides and two bioagents in combination were tested to know their efficacy in } \\
\text { controlling the disease in the field for kharif } 2016 \text {. Out of nine fungicides tested } \\
\text { hexaconazole 5EC }(0.1 \%) \text { and propiconazole } 25 \mathrm{EC}(0.1 \%) \text { were found significantly } \\
\text { superior in controlling the disease. The data reveals that, the per cent relative lesion height } \\
(\% \mathrm{RLH}) \text { was significantly low }(13.85 \% \mathrm{RLH}) \text { in hexaconazole } 5 \mathrm{EC} \text { and propiconazole } 25 \\
\mathrm{EC}(16.05 \% \mathrm{RLH}) \text { sprayed plots respectively, whereas the highest }(68.68 \% \mathrm{RLH}) \text { was } \\
\text { recorded in unsprayed control plot. Significantly higher grain yield was recorded in } \\
\text { hexaconazole 5EC sprayed plot ( } 5703.70 \mathrm{~kg} / \mathrm{ha} \text { ) followed by propiconazole } 25 \mathrm{EC} \\
(5314.81 \mathrm{~kg} / \mathrm{ha}) \text { and the lowest yield of } 3511.11 \mathrm{~kg} / \mathrm{ha} \text { was recorded in the untreated } \\
\text { control plot. The B: C ratio was also found higher in hexaconazole 5EC }(1: 2.65) \text { and } \\
\text { propiconazole } 25 \mathrm{EC}(1: 2.55) \text { sprayed plots compared to other fungicides, bioagents and } \\
\text { untreated control plots. From the present findings it may be concluded that hexaconazole } \\
5 \mathrm{EC}(0.1 \%) \text { and propiconazole } 25 \mathrm{EC}(0.1 \%) \text { were promising fungicides for lowering } \\
\text { sheath blight severity and getting higher grain yield. }\end{array}$} \\
\hline Keywords & \\
\hline $\begin{array}{l}\text { Rice, Sheath blight, } \\
\text { Rhizoctonia solani, } \\
\text { Fungicides. }\end{array}$ & \\
\hline Article Info & \\
\hline $\begin{array}{l}\text { Accepted: } \\
\text { 04 July } 2017 \\
\text { Available Online: } \\
\text { 10 September } 2017\end{array}$ & \\
\hline & \\
\hline
\end{tabular}

\section{Introduction}

Rice is the staple food crop of more than 60 per cent of the world's population. In India rice is the most important food crop occupying about more than 40 million ha. In an attempt to increase the rice production, many varieties have been developed. The disease situation has completely changed with the introduction of high yielding varieties and the associated new technology of crop production. Sheath blight of rice caused by Rhizoctonia solani Kuhn was considered as a minor disease in early sixties. Later on the disease has become a major limiting factor in successful rice cultivation in certain area including Karnataka. This disease is recognised as a high priority constraint to rice production in Karnataka state and there are very few MVs that are resistant to sheath blight. Since commercial rice cultivars are susceptible to sheath blight disease, particularly the high tillering varieties, or have only low level of resistance. As a consequence, the impact of the disease is expected to increase with the increase in rice cropping system. The disease is particularly important in intensive rice production systems due to high plant density and high rate of application of nitrogenous fertilizers which favour the disease development. With the wide coverage of high yielding semi dwarf varieties with high tillering ability, the disease has been aggravated in recent years and 
became the most important disease in rice growing regions. Losses due to sheath blight disease generally vary from 30 to 40 per cent and may be even 100 per cent in endemic areas (Li et al., 2009). The reduction in yield due to the disease has been estimated to vary from 5.2 to 50.0 per cent $(\mathrm{Ou}, 1985$, Hori 1969).

Currently, the disease is managed mostly by application of systemic fungicides and bioagents. Fungicidal sprays have been used successfully to control the sheath blight which is most effective for inhibiting infection lesion enlargement. Timely application of effective fungicides is essential for the management of the disease. Systematic evaluation of commercially available fungicides from time to time is needed for evolving recommendations on chemical fungicides, so that the farmers can choose the fungicides based on the efficacy as well as cost. In this view, the present study was undertaken to appraise the field efficacy of different fungicides and bioagents against sheath blight disease of rice under field conditions.

\section{Materials and Methods}

Field experiments were conducted during kharif 2016 at Agricultual and Horticultural Research station Bhavikere, Chikmagaluru district of Karnataka, which is hot spot area for sheath blight severity. The ruling rice variety, Jyothi, which is highly susceptible for sheath blight was used for the study. The experiment was laid out in RBD with three replications and there are eleven treatments with plot size of $3 \times 3 \mathrm{~m}^{2}$. The fungicides viz., Propiconazole 25EC, Thiophenate methyl 75WP, Tricyclazole 75WP, Hexaconazole 5EC, Thifluzamide 24\% SC, Mancozeb 75WP, Iprobenphos, Carbendazim $12 \%+$ Mancozeb $63 \%$ and biagents (Pseudomonas fluorescence $\left(2 \times 10^{8}\right)$
Trichoderma harzianum $\left.\left(2 \times 10^{8}\right)\right)$ with recommended fungicide Carbendazim $50 \mathrm{WP}$ (as check) were used. The agronomic practices were followed as per package of practices for raising the crop. The fungicides as well as bioagents sprays were given twice. The first spray was given as soon as the disease appeared in field and the second spray was given 10 days after the first spray. The disease severity was recorded ten days after second spray. The PDI was calculated on five plants / sampling unit by counting the number of infected tillers. The disease severity was assessed based on the Standard Evaluation System (0-9) of IRRI during the experimentation. Finally, the grain yield in each plot was recorded and expressed in $\mathrm{kg} / \mathrm{ha}$ at 14 p.c. moisture level. The results of the experiment was analysed statistically and the economics for the fungicides and bioagents were worked out. The cost: benefit ratio was worked out based on the cost of fungicides, spray cost, yield and the market value of rice during 2016.

\section{Results and Discussion}

The results of field experiment revealed that there was significant difference among the treatments in reducing sheath blight severity. The obtained on sheath blight severity and yield are given in table 1 . There was a significant difference among the treatments with respect to relative lesion height $(\%)$ of sheath blight disease and all treatments recorded significantly lower RLH (\%) compared to untreated control plots.

During kharif 2016, the per cent relative lesion height (RLH) was to the tune of 68.68 percent. Proportionately different fungicides controlled the disease effectively. Among the fungicides, the disease severity was significantly less in hexaconazole 5EC (13.85\%) and Propiconazole 25EC (16.05\% RLH) followed by Carbendzim $12 \%+$ 
Mancozeb 63\%WP (18.87\% RLH), Further Carbendazim found effective in reducing the RLH of $25.13 \%$ over untreated control $(68.68 \%)$, bioagents $(37.60 \%)$ and other fungicides. Maximum RLH of $68.68 \%$ was recorded in untreated control plot.

The maximum grain yield and benefit cost ratio was recorded in the plots that sprayed with hexaconazole $(5703.70 \mathrm{~kg} / \mathrm{ha}$ and $1: 2.65)$, propiconazole $(5314.81 \mathrm{~kg} / \mathrm{ha}$ and $1: 2.55)$ compared to untreated control plot $(3511.11 \mathrm{~kg} / \mathrm{ha})$ respectively.

In our study reduction in the relative lesion height per cent among different treatment was reflected in the final grain yield. A significant increase in the grain yield was observed in the plots treated with Hexaconazole 5EC and propiconazole 25EC, compare to other fungicidal and bioagent treatments. The lowest yield was recorded in the unsprayed control plots $(3783.95 \mathrm{~kg} / \mathrm{ha})$. Results are in conformity with Santhakumari and Rahmathniza (2004). The efficacy of trifloxystrobin $25 \%+$ tebuconazole $50 \%$ against sheath blight from West Bengal was reported by Bag (2009). Johnson et al., (2013) found hexaconazole as an effective fungicide against sheath blight of rice. Metaminastrobin 20 SC reduced sheath blight severity in field trials conducted at Andhra Pradesh (Jagadeeswar et al., 2014).

Table.1 Evaluation of fungicides and bioagents against Sheath blight of rice during kharif 2016

\begin{tabular}{|c|c|c|c|c|}
\hline Treatments & $\begin{array}{c}\text { Conc. } \\
(\%)\end{array}$ & RLH\% & Grain yield Kg/ha & B:C ratio \\
\hline $\begin{array}{c}\text { Pseudomonas fluorescens } \\
\text { + Trichoderma harzianum }\end{array}$ & $0.5+1.0$ & 37.60 & 4014.81 & $1: 1.73$ \\
\hline Carbendazim 50WP & 0.1 & 25.13 & 4425.93 & $1: 1.98$ \\
\hline Propiconazole 25EC & 0.1 & 16.05 & 5314.81 & $1: 2.55$ \\
\hline Thiophenate methyl 75WP & 0.1 & 27.49 & 4740.74 & $1: 2.27$ \\
\hline Tricyclazole 75WP & 0.06 & 22.55 & 5000.00 & $1: 2.31$ \\
\hline Hexaconazole 5EC & 0.1 & 13.85 & 5703.70 & $1: 2.65$ \\
\hline Thifluzamide 24\% SC & 0.1 & 28.91 & 4351.85 & $1: 2.28$ \\
\hline Mancozeb 75WP & 0.25 & 31.93 & 4370.37 & $1: 2.21$ \\
\hline $\begin{array}{c}\text { Carbendazim } \\
\text { 12\%+Mancozeb 63\% }\end{array}$ & 0.2 & 18.87 & 5314.81 & $1: 2.38$ \\
\hline Iprobenphos & 0.1 & 31.62 & 4166.67 & $1: 1.96$ \\
\hline Untreated control & - & 68.68 & 3511.11 & - \\
\hline S. Em \pm & & 1.06 & 92.06 & \\
\hline C.D@ 5\% & & 3.12 & 271.57 & \\
\hline CV\% & & 6.29 & 10.39 & \\
\hline
\end{tabular}

Due to non-availability of location specific resistance varieties for sheath blight disease, the chemical control is an important strategy for the farmers to harvest economic yield. Although, resistant variety is a best option to reduce the cost of cultivation but cultivation of such resistant varieties with few protective fungicidal spray will reduce the risk of development of matching virulence by suppressing the population growth of matching virulence. Moreover, poor bio efficacy of the bio-control agents under the 
severe epidemic condition makes the chemical control is an inevitable and ultimate means for sheath blight disease management for the farming community. Though cultivation of resistant variety is the best option for sheath blight disease, but till today no such variety is available to the farmers. Thus, in present situation cultural practices combined with foliar spray of fungicide is the most common practice to manage the disease and even in integrated pest management system need based application of fungicide has been recommended.

Several previous reports enlights that fungicides application increases the yield of rice. In the present study, the fungicide hexaconazole and propiconazole at 0.1 per cent was found superior in reducing the sheath blight severity and increased the grain yield.

Present investigation provides the field efficacy of hexaconazole 5EC $(0.1 \%)$ and propiconazole 25EC $(0.1 \%)$ could be used effectively for the management of sheath blight disease of rice and thus helped for getting higher grain yield and $\mathrm{B}$ : $\mathrm{C}$ ratio.

\section{References}

Bag, M.K., 2009. Efficacy of new fungicide 'Trifloxystrobin $25 \%+$ Tebuconazole $50 \%$ ' 75 WG against sheath blight (Rhizoctonia solani Kuhn) of rice, Journal of Crop and Weed, 5, 224-226.

Hori, M., 1969. On forecasting the damage due to sheath blight of rice plants and the critical point for judging the necessity of chemical control of the disease. Review of Plant Protection and Research. 2: 70-73.

Jagadeeshwar, R., Varma, N. R. G., Reddy, P. R. R., Raju, S. C., Vanisree, S., Reddy, B. G., cfc Dayakar, S. 2014. Screening of new fungicides against location specific diseases of rice occurring in southern Telangana zone of Andhra Pradesh. The Journal of research Acharya $N \quad G$ Ranga Agricultural University, 42, 18- 21.

Johnson, I., Marimuthu, Ramjegathesh, T., Raguchandar, T. Karthikeyan, M., \& Samiyappan, R. 2013. Hexaconazole 5 $\mathrm{SC}$ for the management office sheath blight. Journal of Todays Biological Sciences. Research and Review, 2, 29 35.

Li, F., Cheng, L. R., Zhou, Z, Zhang, Y., Cun, Y., Zhou, Y. L., Zhu, L. F., Xa, J. L., \& Li, Z. K. 2009. QTL mining for sheath blight resistance using the back cross selected introgression lines for grain quality in rice. Acta Agronimica Sinica, 35, 1729- 1737.

Ou, S.H., 1985. Rice diseases. Commonwealth Mycological Institute, Kew survey, England, pp.256-368.

Santhakumari, P., \& Rehmathniza, T. J. 2004. Propiconazole - a new fungicide for sheath blight of paddy. Karnataka Journal of Agricultural Science, 18, 833-835.

Shahid, A.A., Shahbaz M. and Ali M., 2014. A comparative study of the commercially available fungicides to control sheath blight of rice in Lahore. Journal of Plant Pathology and Microbiology. 5(240): 2157-7471.

\section{How to cite this article:}

Ganesha Naik, R., K. Jayalakshmi and Basavaraj Naik, T. 2017. Efficacy of Fungicides on the Management of Sheath Blight of Rice. Int.J.Curr.Microbiol.App.Sci. 6(9): 611-614. doi: https://doi.org/10.20546/ijcmas.2017.609.075 